\title{
Relationship between Teachers' Professional Training and use of Instructional Strategies to Enhance Pupils' Literacy Skills in Lower Primary Schools in Busia County, Kenya \\ DOI: https://doi.org/10.47175/rielsj.v2i3.295
}

\section{| Otwate Paul ${ }^{1,{ }^{*}} \mid$ Nyakwara Begi ${ }^{2}$ | Margaret Mwangi ${ }^{3}$ |}

1,2,3 Department of Early

Childhood and Special Needs

Education, Kenyatta

University, Kenya

*otwatepaul@gmail.com

\begin{abstract}
Children who possess adequate basic language skills develop cognitive and social skills required in life and workplace. It also enhances smooth transition, performance, and retention and completion rate. Teachers with adequate professional training skills exhibits a potential to influent development of language skills in children. The Kenyan policy states that basic education and early learning is compulsory to all children. Therefore, it is relevant that teachers are equipped with adequate training skills to become champions in the realization of the country's overall goal in education sector. This paper presents results from a study conducted in lower primary schools in Nambale sub-county Busia County to establish whether teachers' professional training had an influence in the way teachers use instructional strategies to enhance pupils' literacy skills. This was essential towards improving overall academic outcomes and communications skills in children.

KEYWORDS

language skills; professional training; instructional strategies; literacy skills
\end{abstract}

\section{INTRODUCTION}

Children who possess adequate basic language skills such as reading, writing and communication develop cognitively and acquire adequate communication and social skills (Ngaka \& Masaazi, 2015). Children who are able to read well stimulates thinking skills and are able to become good problem solver in future (Konorio \& Mse, 2016). This is because mastery of literacy skills in schools overall depends on the instructional strategies used and the effectiveness of using these strategies.

The education curriculum in Kenyan primary schools outlines more emphasis on $21 \mathrm{st}$ century skills (Konorio \& Mse, 2016). Young children whose basic language skills such as reading, writing and communication skills have fully developed can communicate well (Konorio \& Mse, 2016). Thus, teachers who are the implementers of the curriculum require adequate professional training skills. Strategies used in classroom during instruction have been closely associated with extent to which learners develop literacy skills and utilize them. The basic education act of Kenya states that children have a right to the access to quality education to enhance transition and completion rates (Konorio \& Mse, 2016). This means that teachers should be adequately trained to enable them use variety teaching strategies which meet diverse learning of needs of learners to enhance their literacy skills (Trudell \& Piper, 2013).

Globally, the National Reading Panel (NRP), a literacy body in the U.S.A revealed low performance in reading and vocabulary skills for grade three children taught by 
inadequately trained teachers (UNESCO, 2007). Duke and Block (2012) reported that more than $63 \%$ certified teachers in the U.S. used only $5 \%$ of their lesson coverage to teach vocabulary grade three learners. The observations implied that these learners could not have fully developed communication skills, which are foundational pillars for quality learning. The findings presented by Luckin, (2008) and Zhao and Frank, (2003) in England reveal that $10 \%$ of the six-year old learners taught by teachers with low mastery of language skills could not read on well.

Findings of a study in England states that $40 \%$ of grade one pupils in who were taught by adequately trained teachers, recorded improved literacy performance in grade two (Ball \& Gettinger, 2009). This situation raises a global concern to find out how professional training of teachers influence use of instructional strategies during instruction (Read on Get on, 2014). Such improved acquisition of literacy skills would translate into enrolment, retention, and successful transition among young children. It is therefore important to note professional training to teachers is necessary to enable practical transferable of literacy skills to children using learner centred and effective instructional strategies. The results of the study noted that children who fail to develop adequate literacy skills such as basic reading, writing and communication becomes at risk of dropping out of the school (UNESCO, 2007).

A research conducted on Early Grade Reading Assessment (EGRA) in Malawi and Liberia reported that only $40 \%$ of children in lower primary taught by certificate college teachers successfully completed reading tasks (Lee \& Son, 2015). This enhanced retention and transition to next grades. Teachers for language skill who are well trained and possess passion in teaching profession can effectively use varied instructional to promote pupils' literacy skills. This would most likely impact a smooth transition and children's strong communication skills in school and holistic life.

In Kenya studies done on causes for dismal pupils' literacy performance in lower primary posit mostly attributes to inadequate professional training among teachers of language (Pfost, Artelet \& Weinert, 2013). Adequately trained teachers exhibit confidence, are articulate and possess a good mastery of the leaner centred instructional strategies (Lapp, Flood \& Farnan, 2011). Consequently, learners who are effectively taught by teachers with aforementioned qualities record improved academic performance in language skills and other subjects. A study conducted by Uwezo (2012) had reported that $30 \%$ of the grade three pupils in Busia County could not successfully manage standard two reading tasks of which inadequately trained teachers was a mong most contributing factors leading to this study in Nambale Sub-county.

\section{Statement of the Problem}

Children with adequate literacy skills stand better chance to remain in school, record high academic performance in not only English but also other subjects taught in school and eventually develop and acquire communications skills. Therefore, teachers of play a significant role to realize this important part of learning. It is however with a great concern that teachers may timely meet this objective when they adequately acquire relevant professional skills through training to effectively use relevant instructional strategies. Studies have researched on causes for low literacy skills in children in developed and developing countries. Nambale Sub-county was ranked amongst the poor performing subcounties in early grade reading levels by Uwezo Kenya (2013) attributing attributed to lack of adequate professional training on teachers on use of varied instructional strategies hence the need for the study in Nambale Sub-county. 


\section{Objectives of the Study}

(i) To establish the instructional strategies used by teachers to enhance literacy skills among grade one pupils' in lower primary schools.

(ii) To determine how teachers' professional training influence the use of instructional strategies in the development of literacy skills among grade one pupils in lower primary schools.

\section{Research Hypotheses}

Ha1: There is a difference in the instructional strategies used by teachers to enhance literacy skills among grade one pupils in lower primary schools

Ha2: There is a difference in how teachers' professional training influence the use of instructional strategies to develop literacy skills among grade one pupils in lower primary schools.

\section{Theoretical and Conceptual Framework}

This study was anchored on Paulo Freire's (1972) theory of Participatory Learning Approach (PLA) to establish the appropriateness use of instructional strategies by teachers to enhance grade one pupils' literacy skills (Freire's, 1972). The theory postulated that teaching language skills to children prepares them to solve education and social problems in a society. Freire recognized that a critical role for a teacher during language instruction is to provide pupils with relevant learner-based interactive and meaningful literacy experiences (Freire, 1972). Therefore, researchers study sought to establish ways teachers' professional training impacted teaching using appropriate instructional strategies such as group teaching, use of well-constructed content-rich questions, direct instructional model and inquiry to promote dialogue and create very interactive teaching sessions (Guo et al. 2012). The theory was selected because teachers' professional training level becomes critical when effectively used to develop learners' literacy skills during early years.

\section{RESEARCH METHODS}

\section{Research Design}

Researchers used a descriptive survey design to provide a description on the actual situation about teacher professional training levels as a denominator to influence the use of instructional strategies to enhance pupils' literacy skills.

\section{Variables}

The independent variables of the study was teachers' professional levels of training measured by establishing professional levels of training among teachers while dependent variable was instructional strategies teachers used measured by determining the frequency of use of the strategies.

\section{Research Methodology}

The researchers adopted a quantitative research method. Mugenda and Mugenda, (2003) acknowledged the use of a descriptive survey design when conducting a quantitative research, hence the preference for the methodology in the study.

\section{Location of the Study}

The study was conducted in Nambale, Busia County because lower primary grades within Nambale recorded low literacy performance in a survey conducted by (Uwezo 2012). 


\section{Target Population}

The target population for the study comprised of lower primary teachers for language in grade one. Grade one was preferred because it is a foundation class which children's early development of literacy skills determines the transition to next grades and levels of education.

\section{Sampling Techniques and Sample Size}

Purposive sampling method was adopted to select Nambale Sub-county and a stratified random sampling technique in selecting teachers for English language from public and private primary schools within the sub-county. A total sample of 55 primary schools were randomly selected and 20 lower primary teachers stratified to take part in the study.

\section{Research Instruments}

The researchers used questionnaires for teachers and observational checklists to collect data. The instruments were used to collect background data for teachers and instructional strategies used. The instruments were piloted in two school; one public and one private to establish and mitigate biasness and ambiguity prior to performance of a re-test and content validity.

\section{Data Collection and Analysis}

During the study, researchers used observational checklist and questionnaires for teachers of language. An observation checklist was administered during a classroom lesson followed by a questionnaire. Data was analysed using descriptive and inferential statistical procedures such as measures of central tendencies and Analysis of Variance (ANOVA) respectively. Results were presented using tables and texts.

\section{Logistical and Ethical Considerations}

First, researchers sought a research clearance to collect data from the Graduate School at Kenyatta University followed by permission sought from relevant authorities such as the National Commission for Science, Technology and Innovation (NACOSTI). The identity of study participants was kept confidential throughout the duration for the study.

\section{RESULTS AND DISCUSSION}

\section{The Instructional Strategies used by Teachers to Enhance Literacy Skills among Grade One Pupils}

In the first objective, the researchers aimed to establish the difference in teachers' use of instructional strategies to enhance literacy skills among pupils in grade one. To achieve the objective, the extend teachers' used instructional strategies was measured by scoring the frequencies and mean difference calculated as presented in the table 1 below:

Table 1. Mean Scores in Teachers' Use of Instructional Strategies

\begin{tabular}{|c|c|c|c|c|c|}
\hline Type of Instructional Strategy & $\mathbf{N}$ & Minimum & Maximum & Mean & $\begin{array}{c}\text { Std. } \\
\text { Deviation }\end{array}$ \\
\hline & 20 & .00 & 1.00 & .4000 & .50262 \\
\hline Use of directed reading thinking activity & 20 & 3.00 & 4.00 & 3.750 & .44426 \\
\hline Use of question-answer strategy & 20 & 3.00 & 4.00 & 3.850 & .36635 \\
\hline Use of visualization text & 20 & 2.00 & 4.00 & 3.400 & .75394 \\
\hline Use of read-aloud strategy & 20 & 3.00 & 4.00 & 3.700 & .47016 \\
\hline Use of classification of charts & 20 & 2.00 & 4.00 & 3.500 & .60698 \\
\hline
\end{tabular}


Use of cooperative learning strategy

Use of what I know, what I want to learn and what I have learnt (K-W-L)

Use of direct instructional model (DIM)

Use of I do, We do, You do strategy

Valid N (listwise)

$\begin{array}{llllr}20 & 2.00 & 4.00 & 3.300 & .80131 \\ 20 & 2.00 & 4.00 & 3.600 & .59824 \\ 20 & 1.00 & 4.00 & 2.000 & 1.21395 \\ 20 & 1.00 & 4.00 & 2.300 & 1.34164 \\ 20 & & & & \end{array}$

As shown in table 1 above, the findings of the study reveal most teachers sometimes used instructional strategies because they rated sometimes with a mean of 3.5. The researchers found out that teachers mostly used the following instructional strategies; question-answer, read aloud, use of visual texts among others.

To determine whether there was a difference in teachers' use of instructional strategies between public and private primary schools, the researchers generated the following null hypothesis and went ahead to test it.

\section{H01: There is no difference in the instructional strategies used by teachers to enhance literacy skills among grade one pupils in lower primary schools}

T-test analysis was used to establish the significant level of the difference in teachers' use of instructional strategies between those in public and private lower primary schools. The results are presented in table 2.

Table 2. Independent Sample t-test for Equality of Means by Type of Schools

\begin{tabular}{|c|c|c|c|c|c|c|c|}
\hline \multirow{4}{*}{$\begin{array}{l}\text { Average use of } \\
\text { instructional strategies }\end{array}$} & \multirow{4}{*}{$\begin{array}{l}\text { Equal variances } \\
\text { assumed } \\
\text { Equal variances } \\
\text { not assumed }\end{array}$} & \multicolumn{2}{|c|}{$\begin{array}{c}\text { Levene's } \\
\text { Test for } \\
\text { Equality of } \\
\text { Variances }\end{array}$} & \multicolumn{4}{|c|}{ t-test for Equality of Means } \\
\hline & & $\mathbf{F}$ & Sig. & $\mathbf{T}$ & Df & $\begin{array}{l}\text { Sig. (2- } \\
\text { tailed) }\end{array}$ & $\begin{array}{c}\text { Mean } \\
\text { Difference }\end{array}$ \\
\hline & & .587 & .453 & -2.606 & 18 & .018 & -.319 \\
\hline & & & & -2.675 & $\begin{array}{r}16.43 \\
7\end{array}$ & .016 & -.319 \\
\hline
\end{tabular}

Table 2 above shows the difference between the mean scores for teachers' use of instructional strategies was -.319 with a significant level of .018 (2-tailed). The negative sign imply the dismal difference in means, hence no significance. Empirically, the results imply that the extent of teachers' use of instructional strategies between those in public and private primary schools was statistically significant. Hence, the null hypothesis was rejected, and it's alternate which states that there was a difference in the instructional strategies used by teachers to enhance literacy skills among grade one pupils was accepted.

The results of this study are consistent with a prototype experimental research conducted by Dunlosky et al. (2013), in the 56 primary schools in the United States to investigate the impact of using reading aloud strategy on students' learning outcomes. The findings revealed the group taught on reading aloud improved compared to their counterpart group which did not use the strategy.

The findings of this study are consistent with that of Keengwe, Mbae \& Ngigi (2015), who conducted a longitudinal study involving 23 pre-schools in both rural and urban centres of Japan on reading levels. The findings indaicted majority of pre-school teachers who used a combination of read aloud, directed thinking activity and visualization texts significantly improved up $(68.7 \%)$ on listening, reading and fluency skills of pre-school children (Keengwe, Mbae \& Ngigi, 2015). 
The results of the study imply that language of the catchment area is very paramount in development of literacy levels among pre-school children and enhances smooth transition from home to pre-school and later grades. This is because during instruction using language of mother tongue, children and teachers develop a direct connection on learning experiences and ease mastery of content as pointed out by (Nyakwara, 2014) in his study in Nairobi County.

\section{Teachers' Levels of Professional Training and use of Instructional Strategies to enhance Pupil's Literacy Skills}

Researchers sought to determine the influence of teachers' professional training on use of instructional strategies in the development of literacy skills among grade one pupils.

To achieve this objective, researchers used questionnaires to score the level of professional training for all sampled teachers at certificate, diploma, degree and master training level and descriptive analysis of the results presented in table 3.

Table 3. Mean Scores on Professional Levels of Training for Teachers on use of Instructional Strategy

\begin{tabular}{llcrr}
\hline & $\begin{array}{l}\text { Teachers' Levels of } \\
\text { Professional } \\
\text { Training }\end{array}$ & N & Mean & $\begin{array}{c}\text { Std. } \\
\text { Deviation }\end{array}$ \\
\hline $\begin{array}{l}\text { Average use of } \\
\text { instructional } \\
\text { strategies }\end{array}$ & Certificate & 13 & 3.197 & .253 \\
\hline
\end{tabular}

The results show majority of teachers were trained to certificate level. Teachers who had trained to a diploma level demonstrated an average level on use of instructional strategies at a mean of 3.397 compared to teachers with certificate (3.197). The findings imply a close association between the two levels of training. No teacher had trained to a degree and master level. A nulls hypothesis was generated as stated below to establish the differences in levels of training and use of instructional strategies.

H02: There is no difference on how teachers' level of professional training influence the use of instructional strategies in the development of literacy skills among grade one pupils

The t-test analysis was used to test the hypothesis. The results were presented in Table 4.

Table 4. Independent Sample t-test for Equality of Means in Teachers' use of Instructional Strategies across Teachers' Level of Professional Training

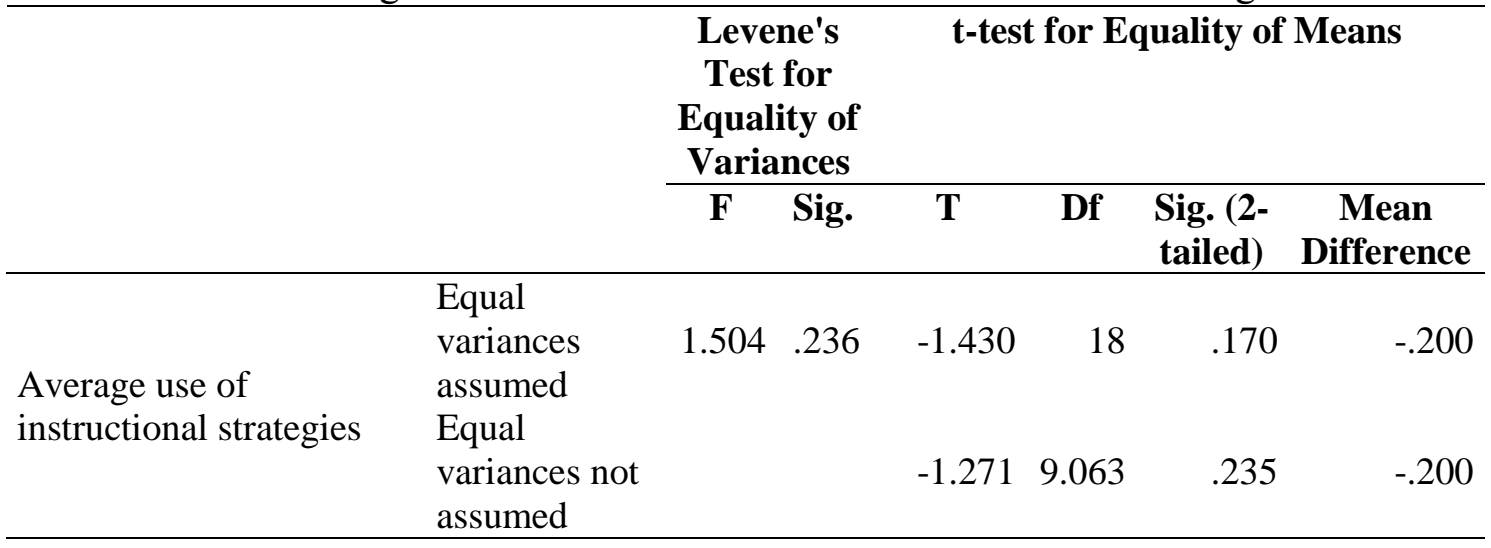


Results in table 4 above show the correlation coefficient difference in level of professional training on use of instructional strategies was; $p=.170$ implying the relation was not significant. Therefore, the null hypothesis was retained while the alternate hypothesis which stated that there is difference in how teachers' levels of professional training influence use of instructional strategies was rejected.

The findings of the study concur with a study by Eithnel et al. (2012), who observed that most teachers who had a training degree frequently incorporated varied teaching strategies during instruction compared to teacher with certificate and diploma holders.

On the other hand Ngaka and Masaazi (2015) in a study conducted in England revealed that there existed a disparity between children's reading fluency levels taught by teachers with various levels of professional training. However, those children taught teachers language skills by teacher trained to degree and masters levels reported improved and fully developed literacy skills during post-assessment. The findings collectively demonstrate a relationship between higher levels of professional training and improved acquisition of literacy skills among learners taught by these teachers.

\section{CONCLUSION}

Concerning the first objective, to determine the instructional strategies used by teachers to enhance pupils' literacy skills, the findings have revealed that most teachers used instructional strategies. However, teachers did not adequately use variety-teaching strategies simultaneously. This means that most of the learners' differential learning needs were not adequately met. Hence, there is need for the government to provide additional training on teachers for grade one, specifically on pre-service and in-service literacy instructional programs.

Second objective aimed to determine the influence of teachers' professional training on use of instructional strategies to enhance literacy skills among grade one pupils. The results established that all teachers with certificate and diploma sometimes used instructional strategies. The difference in teachers' use of instructional strategies was not significant. Teachers did not adequately use varied teaching strategies during a single lesson. Also, none of the teacher involved in the study had trained to a degree and masters level. Therefore, in order to enhance literacy levels among learners, the government of Kenya should support teachers to aim high training levels and compliment this by attending formal educational literacy programs on instruction.

\section{Recommendations}

Recommendations have been made for policy, practice and to inform further areas of research as follows:

\section{School Management}

Concerning the findings of this study, school management should support teachers through provision of adequate and variety of English language learning resources and literacy trainings. This will motivate and challenge teachers to adopt and sustain the use of variety instructional strategies. As a result, learners' diverse learning needs will be accommodated translating to smooth transition. The study had revealed that majority of the teachers did not use direct instructional model considered as one of the best appropriate teaching strategies. 


\section{Lower Grade Primary Teachers}

All teachers in lower grade primary schools should start embracing use of variety instructional strategies. In addition, teachers should be willing to advance in their levels of professional training. This might help them better understand and fulfil the diverse learning needs of different learners to develop their literacy levels. This is because the study had established that majority of teachers did not use variety instructional strategies. Additionally, no teacher had trained beyond diploma level and hence a need for the government to support quality high training for all teachers in primary schools.

\section{Kenya Institute of Curriculum Development (KICD)}

The Kenya Institute of Curriculum Development (KICD) should closely collaborate with Ministry of Education, Science and Technology to develop college training curriculum content which has informs use of variety instructional strategies. This initiative might regularly inform teachers on the individual learning needs among different learners, thus understand better the need to use appropriate and variety instructional strategies. This is because the results had established that some teachers did not adequately use direct instructional model and cooperative learning strategies.

\section{REFERENCES}

Ball, C., \& Gettinger, M. (2009). Monitoring children's growth in early literacy skills: Effects of feedback on performance and classroom environments. Education and Treatment of Children, 32(2), 189-212. Retrieved from http://www.jstor.org/stable/42900018

Duke, N., \& Block, M. (2012). Improving reading in the primary grades. University of Michigan, vol. 22, no. 2. Http://www.futureofchildren.org

Dunlosky, J., Marsh, E., Nathan, J., \& Willingham, T. D. (2013). Improving students' learning with effective learning techniques: Promising directions from cognitive and educational psychology. Association for Psychological Science. SAGE.

Eithnel, Co. and Hans, (2012). Literacy in early childhood and primary education. National Council for Curriculum and Assessment (NCCA).

Guo, Y., Connor, C., Yang, Y., Roehrig, A., \& Morrison, F. (2012). The effects of teacher qualification, teacher self-efficacy, and classroom practices on fifth graders' literacy outcomes. The Elementary School Journal, 113(1), 3-24. Doi: 10.1086/665816

Keengwe, J., Mbae, J. \& Ngigi, S. (2015). Promoting global literacy skills through technology-infused teaching and learning. Hershey, PA: Information Science Reference.

Konorio, F., \& Mse, G. (2016). Curriculum implementation: Strategies for improved learning outcomes in primary schools in Kenya. Journal of Curriculum and Teaching. Vol. 5, No. 1.

Lapp, D., Flood, J. \& Farnan, N. (2011). Content area reading and learning: Instructional strategies. Mahwah, N.J: Lawrence Erlbaum.

Lee, J., \& Son, J. (2015). Two Teacher Educators' Approaches to Developing Preservice Elementary Teachers' Mathematics Assessment Literacy: Intentions, Outcomes, and New Learning. Teaching \& Learning Inquiry: The ISSOTL Journal, 3(1), 47-62. doi:10.2979/teachlearninqu.3.1.47

Mugenda, O. and Mudenda, A.G. (2003). Research methods, quantitative approaches. ACT, Nairobi. 
Ngaka, W., \& Masaazi, F. (2015). Participatory literacy learning in an African context: Perspectives from the Ombaderuku primary school in the Arua district, Uganda. Journal of Language and Literacy Education.

Nyakwara, B. (2014). Use of a Mother Tongue as a Language of Instruction in Early Years of School to Preserve the Kenyan Culture. Journal of Education and Practice, Vol. 5 No.3. www.iiste.org

Pfost, M., Artelt, C. \& Weinert, S. (2013). The development of reading literacy from early childhood to adolescence empirical findings from the Bamberg Biks longitudinal studies. Bamberg: University of Bamberg Press.

Trudell, B. \& Piper, B. (2013). Whatever the law says: Language policy implementation and early grade literacy achievement in Kenya. Current Issues in Language Planning, 15(1), 4-21. http://dx.doi.org/10.1080/14664208.2013.856985

UNESCO, (2007). Early childhood and development. Nairobi: Eastern and Southern Africa Regional Office.

Uwezo (2012). East African Report of July 21 ${ }^{\text {st }} 2011$. Retrieved on $27^{\text {th }}$ March 2012 from http://www.vijana.fm/2011/07/04/eat-africa report.

Zhao, Y., \& Frank, K. A. (2003). Factors affecting technology uses in schools: An ecological perspective. American Educational Research Journal, 40(4), 807-840. 